\title{
Fighting in the Fightschools late XVth, early XVIth century
}

\section{Daniel Jaquet, University of Geneva}

Abstract - This article discusses the role played by Fightmaster (master-at-arms, Schirm- or Fechtmeister) in the Fightschools (Fechtschulen) taking place in the swiss cities at the end of the middle ages. The strong link between these lessstudied events and the practice of martial arts according to the technical literature (Fechtbücher) will be examined, as well as the figure of the Fightmaster.

By collecting references out of normative documents regarding those events, it is possible to sketch both the fighting praxis inside the fightschools and the expertise of the Fightmaster in relation with the town's authorities. Doing so, the questions of the professional performances, the reputation and the representation of the Fightmaster will be addressed. This approach will be illustrated by the case study of a master at arms, Peter Switzer

Keywords-Fencing schools (Fightschool), Fightbook, master-at-arms (Fightmaster), duel, art of combat.

"Item you will learn to fight properly [T.N.: also meaning "courteously"] and effectively with the long sword." Thus begins a technical treatise codifying weapon handling in the ancient Swiss Confederation in the second half of the fifteenth century. This Fightbook (Fechtbuch) is part of a martial tradition represented in a corpus of over seventy manuscripts (Forgeng, 2012:165) from the fourteenth to the mid-sixteenth century, the majority of which comes from German speaking areas 2 . Who are the authors of these treatises? To which kind of audience are they intended for? And most importantly, what is the context(s) in which the gestures as described are performed?

I propose in this short article first to consider how the art of fighting (Kunst des Fechtens) is presented by the authors of the Fightbooks, as well as their self-representations, pointing out their social status and their connection with temporal authorities. Then, I address the issue of both playful (schimpf) and serious (ernst) dimension of the art and its relationship with different regulated praxis of combat, especially in the context of socioprofessional Fightschools (Fechtschulen). Finally, I illustrate my argumentation with a case study of a "master of the sword" in the cities of the ancient Swiss Confederation and southern cities of the Empire, mainly out of normative documents.

${ }_{1}$ Item wiltu lernen hoflich und weidalich mit dem langen schwert vechten Hugo Wittenwiler Fightbook. Bayerische Staatsbibliothek, München, Cgm 558, fol 125r. See remarks on Hils (1985:86-87). Edition and studies in Jaquet (2005) and english translation in Hull (2008:211-222).

2 The majority of the corpus is described in Leng et al. (2008). For a general overview see Anglo (2000), for a short survey of the German tradition see Kiermayer - Forgeng (2007). 
The putting of this art of fighting in writing is part of the pragmatic literacy (Pragmatische Schrifftichkeit), especially of the technical literature (Fachliteratur) ${ }^{3}$. The different author's intents reflect these trends, but introduce the codification of fighting techniques embodied knowledge -, through different attempts of notation of movement with or without illustration ${ }^{4}$.

In medieval thought, this art is part of the mechanical arts (artes mechanicae)5, especially of the courtly arts (mhg. Hofkunst, lat. theatrica). Johannes Purgold, who compiles various customary rights in his Eisenacher Rechtsbücher at the turn of the fifteenth century, described the courtly arts as follows:

"The courtly art has under it three main crafts. The first is the fighter, he is a major craft and has under him several crafts, such as the fighter [T.N.: schermer differs from fechter, see footnote 32, original footnote no. 32], the runner, the jumper, the rider, the one who trust thrust, the one who defends and those alike."

Under the latter mechanical arts category fall all crafts related to entertainment (games, proto-sports, leisure), but also allow, in the context of their pragmatic literacy, "the selfrepresentation of aristocratic and middle-class circles." (Hils, 1985a:16) ${ }^{7}$. In the courtly

3 "[...] zum weiten Kreis der pragmatischen Schriftlichkeit und innerhalb dessen zum enger begrenzten Feld der Fachprosa des Spätmittelalters.” in Bergner-Giessauf (2006:31). On the concept of pragmatic literacy, see the works of the research project SFB 31 of the Munster University, Representatives, fields, and forms of pragmatic written record in the Middle Ages. Numerous publications (1986-1999) including the final report: Meier (2003. In relation with Fight books in that matter, see Müller (1992).

4 For J.-D. Müller (1992:251): "Es gibt fortlaufend gereimte Verslehren, ein in Merkversen konzentriertes Regelwissen, ergänzt durch deren Prosaauslegungen, Prosabeschreibungen von Bewegungsabläufen samt Bildfolgen mit und ohne Beischriften sowie registerartig zusammengestellte Termini und Kunstregeln. Jeder Typus kann für sich auftreten, doch meist ist es eine Kombination aus mehreren." For S. Anglo (2000:21): "Analytical studies of combat technique, statements of general principles and purpose, ordered rules and procedures, and experimental schemes to record and notate movement and to systematize fighting according to the personal practice of individual master."

5 "Die Fechtkunst gehörte nach der klassischen Einteilung der Künste, die bis zum hohen Mittelalter galt, nicht zu den artes liberales, den sieben freien Künsten, sondern zu den artes mechanicae, den unfreien Künsten." in Bodemer (2008:27), also in Hils (1985), Müller (1992), etc..

${ }^{6}$ Dy hofekunst hat undir er dry houpthantwerg. Daz erste die vechter, und ist eyn houptandwerg und hat vel andir hantwerke undir em alz die schermer, renger, sprenger, ryter, stecher, schutzcen unde derglichin. Edited in Rondi (1950:250). I shall thank Matthias Johannes Bauer for this reference.

7 "Die Fachprosa ist im Rahmen der Hofkünste aber auch die Bewahrerin aller Kunstfertigkeiten, die nicht der unmittelbaren Befriedigung elementarer Lebensbedürfnisse, sondern Spiel, Sport und Unterhaltung dienten, die zugleich aber auch der Selbstdarstellung adeliger und bürgerlicher Kreise und ihrem Bedürfnis nach Repräsentation genügten." See also on this matter and the connection to the Trachtenbuch, the forthcoming article of Christian Jäser: «Ernst und Schimpf Fechten als Teil städtischer Gewalt- und Sportkultur » from a paper given at the 2012 symposium in Villa Vigoni: Agon und Distinktion - soziale Räume des Zweikampfs zwischen Mittelalter und Neuzeit. 
arts are also ranked the secret or magic arts 8 . Like those, under the pen of the glossators of the Johannes Liechtenauer's Epitome, the arts of combat are transmitted through secret and hidden words (mitt verborgen vnd verdeckten worten), so that art is not commonly disclosed (darumb daz die kunst nitt gemain solt werden ${ }^{9}$ ). Thus, the defense of an art just or correct $^{10}$, against rivals 11 or to prevent it from being disclosed to the "rurals"12 is a topos that appears within the entire corpus.

The intended audience, according to the authors who specify it, is twofold: on the one hand the established aristocracy, on the other hand, the "fighters", the latter category includes all social strata able to fight13. Entering the sixteenth century, this duality is more pragmatically formulated and the relationship between the practice of the art and the burghers is attested. For example, in 1539, Fabian Auerswald in the prologue of Ringer kunst: fünff vnd Achtzig stücke... explicitly addresses people of high or low status ${ }^{14}$.

"Social distinctions and class identities play a prominent role in these textes, atlhough perhaps in unexpected ways: where class is emphazised, the text generally works as a means for those of a non-noble background to associate themselves with a knightly art,

8 Some Fightbooks are part of collections (id est: volume containing different texts, some of the
same genre, some of miscellaneous genres) including texts, recipees or treatises about alchemy,
metallurgy, astronomy, medicine, magical skills, etc. For examples: Anonymous of 1389
(Nürnberg, Germanisches Natonalmuseum, Hs 3227a) see Leng (2008:16-17) ; Hans Talhoffer,
[Gothaer Codex], 1448 (Gotha, Universitäts- und Forschungsbibliothek, Chart. A 558), see Leng
(2008:42-44) ; Hugo Wittenwiler, cited in footnote 1; anonymous [Kolner Fechtbuch], first part of
the XVIth c. (Köln, Historisches Archiv der Stadt, Ms Best. 7020), see Bauer (2009:36) ; etc. 9 After Sigmund ain Ringeck quoted in Wierschin (1965:6). The first anonymous glossator in 1389 (mistakenly reffered to as Hanko Dobringer) specifies: Darumb daß sij nit yderman vernemen noch versteen sol. Quoted in Zabinski (2010:140).

10 For example: Hans Talhoffer, 1459 (Det Koneglige Bibliothek, Kopenhagen, Thott $2902^{\circ}$ ) fol.1v : Jtem die Sloß der rechten kunst nach dem alß die maister Die abgetailt hand von genähe wegen Daz ouch billich zu behaltent ist wen diß ist der recht grunde. On the institutionalisation of the art, see for instance Müller (1994:358-362).

11 For example: Anonymous of 1389 (op.cit. footnote 9), fol.3r: Und hat daß getan / durch der leichtfertigen schirmaister willen / dye irer kunst gering wegen / daß sein kunst von den selbigen maistern nicht gemain nach geoffenwart sol werden solichen lewten die dye kunst in wieden nicht behalten alß dan der kunst zu gebört. Quoted after Zabinski (2010:140).

12 Fiore dei Liberi, [Pisani Dossi version] 1410, fol.1r: ne quando inter rurales nullatenus propaletur. Edited in Rubboli-Cesari (2002:31). His follower, Filippo di Vadi in 1482, specifies : a ciò che mai, per modo alcuno, tale industria arte e dotrina non pervenga a le mane de homini rusticali e di vile condizione. Edited in Rubboli-Cesari (2005:34).

13 Fiore dei Liberi, same manuscript as the latter footnote: Quapropter ab hoc precioso archano censeo reppellendos et per opositum ad ipsum comitandos reges duces principes et barones, ceteros denique curiales et alios babiles in duello. Edited in Rubboli-Cesari (2002:31). The same is to be found in the german tradition, see Peter von Danzig in his preamble in 1452: die kunst fürsten vnd herren Ritt ${ }^{\circ}$ nd knechten $2 u^{\circ}$ gehört das sï die wissen vnd lernen sullen. Edited in Hagedorn (2008:6).

14 von hohen oder nidern Stand. Quoted in Welle (1993:162). 


\section{and so give form to their aspirations for upwartd social mobility." (Forgeng 2012:172)}

This "social mobility" of the burghers in competition with the aristocracy has been the subject of numerous studies for the end of the fifteenth, but especially for the sixteenth century ${ }^{15}$. In connection with the handling of weapons, their carrying rights and the culture of violence conceptions, see Tlusty (2011) and Morsel (2000 and 2004) for the Holy Roman Empire; Verrier (1997) for Italy and Briost et al. (2002) for France. In relation with the corpus of Fightbooks, the question of the social status of masters and practitioners has been addressed by most of the authors of reference. The one who wrote the most about the issue is Hils (1985a, 1985b and 1995), including research investigating the legislative texts ${ }^{16}$. More recently Wetzler (2012:68) asserts that martial arts were practiced by every social strata in the late Middle Ages and early Renaissance ${ }^{17}$.

Some of the Fightbook's authors claim a connection with the courtly world. In short prologues, preambles or dedication's forms (textual or figurative), the authors who mentioned connections to this world can be ranked in three categories: those who present themselves as fightmasters (fecht-or schirmmeister, master-at-arms) in the service of a court ${ }^{18}$; those who dedicate their works to princes without mentioning their function to the court ${ }^{19}$ or those who do not dedicate their works. Among the latter category, it is still possible to distinguish between authors who claim guild or brotherhood membership or those recognized by one of these20. The Fightmaster's occupation can

15 For a current state of the issue, especially about representations, see Rösener (2008). For the relation between burghers and warfare in the central and late Middle Ages see Chandler in this volume Chandler, 2013, p. 106)

16 On the matter of campiones, see also Neumann (2010:184-188)

17 "Die Fechtkunst "gehörte" also nicht einer einzelnen Schicht, sie ist eine Kulturtechnik, an deren Entwicklung über die Jahrhunderte ganz unterschiedliche Menschen teilhaben; sie ist ein diskursiver Raum, in dem man sich über Standesgrenzen hinweg verständigt, verständigen muss [...]." Wetzler 2012:68).

18 Notably Sigmund ain Ringeck, Ott the Jew, Paulus Kal, Hans Talhoffer (version of 1467). See Hils (1985a:215 and 247-248) even if he does not mention Ott the Jew. About Paulus Kal and Hans Talhoffer and their connections to the swabian aritocracy, see Stangier (2009:73-93).

19 Notably Fiore dei Liberi, Filippo Vadi and some books of Hans Talhoffer (Konigsegg codex and Berlin codex)

20 For example: The Saint Marcus Brotherhood's Griffin is represented in Peter Falkner's Fightbook of 1495 (Kunsthistorisches Museum, Wien, Ms KK5012, fol.57v), mentionned in Tobler (2010:15). The latter also appears in the statutes of the fightguild in Franfurt (Franckführter Fechtordnung), see Universitätsbibliothek, Augsburg, Cod.I.6.2 ${ }^{\circ} .5$, fol.9v, edited in Dupuis $(2009: 22)$. In the same document Peter Schwyzer is to be found, see footnote 56. Another example with Hans Talhoffer who bear upon his coat of arm the same griffin in the 1459 manuscript (Det Konelige Bibliotek, Kobenhavn, Ms Thott 290.2 , fol.102r). The master also appears on the brotherhood statutes of 1482 see Wassmansdorff (1877:139), Hils (1985a:175) also mentionned in Meier (2010:43). 
indeed be performed outside of the courtly world, in other socio-professionnal context such as within the cities under the auspices of guilds or brotherhoods as discussed below.

\section{FIGHTSCHOOLS: "FOR A FREE FIGHT IN GOOD COMPANY IN A CIRCLE, FOR SOME COINS OR TO THE HIGHEST BLEEDING WOUND"}

The art of combat bears a duality: the playful (schimpf) and serious (ernst) dimension. In the writings of the first glossator of the Epitome in 1389, the following advice is given:

"[...] and the more you train yourself in play the more you will think of it in earnest. For practice is better than art, your exercise does well without the art, but the art is not much good without the exercise. 21 "

Also discoursed by italian masters ${ }^{22}$, this duality is further discussed by Liechtenauer's later glossators. The most verbose on the matter is Hans Lecküchner. He explains that some techniques with a more scenic dimension are meant for Fightschools (auff der Schull), see fig. 1. This element is in favor of entertainment and display of fighting skills in the context of public competitions. The master states that his lessons can be used in a playful or in a serious context (yn schympff oder yn ernnst $)^{23}$.

21 [...] Vnd ube dich dorynne deste mer yn schimpfe / zo gedenkestu ir deste bas in ernste / wen ubunge ist besser wenee kunst / denne übunge w tawg wol ane kunst aber kunst tawg nicht wol ane übunge / Quoted after Zabinski (2010:133)

22 Fiore dei Liberi and his follower Filippo di Vadi in their prolog, distinguish the actions performed by anger ( $d a$ ira), to defend one's life (per la vita) and those that the fighter executes courteously (de cortesia). About wrestling, Fiore dei Liberi (Pisani Dossi Version, fol.1r) states : E sopra l'arte de l'abraçar che se fa a guadagnar le prese tal nolta se fa da ira e alguna nolta per la nita e sono prese e zoghi che non se pò çugar de cortesia, anche sono coghi pericolusi da çugar. Edited in Rubboli-Cesari (2002:31).

23 Hans Lecküchner deals with messer fighting techniques. The above quotations are from the 1482 Fightbook, quoted after Müller (1994:375). 


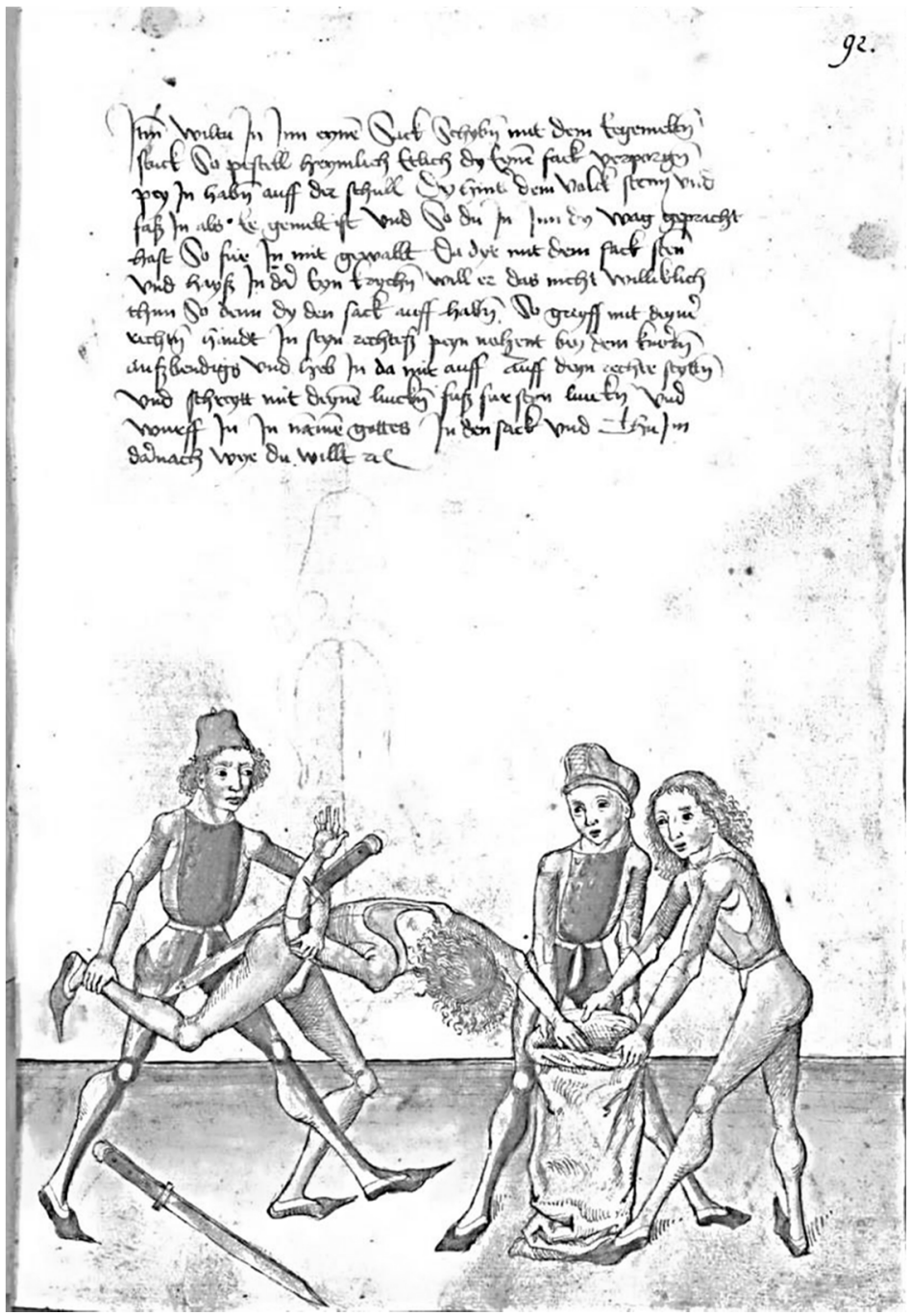

Fig. 1 : Hans Lecküchner, Kunst des Messerfechten, 1482.

(C) Bayerische Staatsbibliothek, Munich, CGM 582, $f^{\circ} 92 r$.

The issue of the playful or serious dimension transposed on the technical level of execution is hardly defined. The difference is made more by the purpose of the gesture, less by its mechanical/bodily execution. Welle (1993:2), considering knightly games, especially wrestling, also believes that this duality do not actually differ in motor actions. The game serves on one hand as training and on the other hand allows the display of its 
"technical culture"24. Thus, it is possible for the fighter to train a gesture in a playful context and to execute it in a serious situation.

The same logic is to be found in the chivalric praxis linked to the different events commonly referred to as "tournaments" 25 . The martial gesture executed during those regulated events will allow the fighter to train to defend his life against a blow of a spear, a poleaxe or a sword, and also at the same time to win an award, to gain recognition or favors of both peers and elites. These events, initially reserved for the aristocratic fighting elites, slipped into the most humble classes in the late middle ages ${ }^{26}$. Moreover, the influence of these highly ritualized form of combat and their roots in the various praxis of trial by combats shaped not only the Renaissance duel of honour, as pointed out by Cavina (2005:27-30, 38-40), Neumann (2010:215) 27 and Priezel (2012:118) 28 , but also the ritual and the competitive side of the Fightschools.

Another parallel can easily be drawn with another form of game, the "game of the bow" (jeu de l'arc). Ordinances of temporal authorities in the Kingdoms of England, then France, aim to reduce the game practices of their subjects to only the "game of the bow", at the expense of other physical games or gambling. It was certainly not only a means of regulating social violence, but rather a way to have qualified archers for military purposes (Mehl 1990:360-364, Contamine 2003:363).

Mehl (2010:271-276) has demonstrated, in his research on games and its relationship with the authorities in the Kingdom of France from the thirteenth to the sixteenth century, the tensions to allow regulation, and ultimately to control the competitive activities, especially within cities. He came to the same conclusions as Schaufelberger (1972), stressing the need for control of the space dedicated to these praxis, as well as the relation to the various protagonists organizing and participating, especially guilds and brotherhoods. From the sixteenth century onwards, Tlusty (2011:221) showed the role played by "shooting societes, sword-fighting schools and sword dance" for both the social and the military ends.

Thus, the study of competitive, leisure and festive activities proves to be of primary importance to address issues related to the handling of weapons, but also the wider

24 "In diesem Sinne dient das Spiel u.a. der Einübung und Demonstration ritterlicher Kulturtechniken. Spiel und Arbeit, unterschiedlich nur in ihrem Affektstandard, unterscheiden sich nicht in ihren motorischen Handlungen." Welle (1993:2).

25 For a general state of the issue, see the various contributions in Fleckenstein (1986). For a good survey, see Barber - Barker (1989).

26 See the latter footnotes, but especially on the lower classes tournaments see Bove (2003:135-163), van der Neste (1996) and more recently Nadot (2012) who points out for example (p.14), the various interdictions to joust on barrels by the echinal bans of Flanders towns. 27 "Die Bedeutungsvarianten des gerichtlichen Zweikampfes lassen sich bis auf einzelne Trands weder chronologisch fixieren noch in ein Fortschrittsmodel einbinden, das den Weg vom gottesgerichtlichen iudicium pugnae zum Ehrenduell der Moderne nachzeichnet."

28 "An die Stelle der Logik des Gottesurteils ist hier jene des frühneuzeitlichen Duells getreten." 
inherent socio-cultural and socio-professional issues (Heers, 1982:9). In addition, it is interesting to note that if tournaments - and to a lesser extent archery - have occupied historians, none of these activities have a technical literature comparable in terms of quality and quantity with the Fightbooks.

Within the cities of the ancient Swiss Confederation, the first mention of "play of sword" (jeu de l'épée) is found in the accounts of the city of Estavayer in 145429, further ones follow in the accounts of the town of Orbe in 1459 and $1462^{30}$. Similar references are found beyond the ancient Swiss Confederation, in Flanders cities ${ }^{31}$ for example. Behind these mentions appears a practice akin to a remunerated demonstration of martial skills before a middle-class public. Were those events episodic? Who were the practitioners? Some of these questions are answered in the investigation of a regulated fighting practice within the cities from the second half of the fifteenth century: the Fightschools (Schirm- or Fechtschulen32). According to Tlusty (2011:211): “Fencing or sword-fighting schools were not permanent institutions, but public competitions or traning sessions offered by a traveling swordman."

For Hauser (1987:173): "Between the fourteenth and sixteenth century, in almost all Swiss cities are found fencing teachers, masters-at-arms and fencing schools." However, to agree with this statement, terminology and definition of such practices must be delineated first. Fighting with swords is at the end of the Middle Ages, in a world "used to the sword", "a hobby and a popular pastime"; fightschools and shooting competitions are "middle-class leisure and commonplaces" (Schubert, 1995:238-239). To understand the praxeological shifts between handling of warfare weapons reserved to a fighting elite to the widespread of regulated praxis of a civilian fencing, the steps of the "late medieval trend to professionalisation" must be examined, especially in relation to craft guilds grouping

29 A Guillaume Larcaut, par le comandement de tout le consel, pour aulmône faite eis ppovre Sarragin qui se sont fait cristient. xij s. / Chiez. Piere Saget, pour le vin beuzpar les dis Sarragin et certain companyon qui juèrent de l'espée à due main en la place, la dimenche aprest Saint Bartholomé [26 août 1459] par le comandement de la plus grant partie du consel. xij d. / A piere Saget. la dimenche aprest feste translation Saint Martin [11 juillet 1462] pour huit pot de vin doneir eis compagnyon de Yverdon et a certain aultre estrangiez qui juarent à l'espeaz à dux main. iij s. iiij d. Edited in Barbey (1911:289, 1912:43).

30 'Jeux, conrey. - L'un des plus en honneur était le jeu de l'épée. Le dimanche avant la fête de la Ste-Madeleine plusieurs bourgeois d'Yverdon, de Neuchâtel, de Payerne et de Grandson se rendirent à Estavayer, dans la maison de noble Antoine Angleis pour le jeu de l'épée. 1454. Les seigneurs le conseil et plusieurs bourgeois assistèrent au jeu. On fit donner aux acteurs 12 pots de vin, comptés à 7 sols les 12 pots." Translated in Grangier (1905:81). I shall thank Olivier Dupuis to have drawn my attention to those quotations.

31 (27 février 1448) Des compagnons esquiermisseux de l'espee a deux mains [de] faire une feste et esbatement et avoir grace de le faire publier par les bonnes villes. LA GRANGE, Antoine de (1893): Extraits analytiques des registres des consaulx de la ville de Tournai 1431-1476, Tournai. p.133. Quoted in Contamine (2003:361).

32 The term fechten slips from its original meaning "fight" into "fence". For a lexicographic approach of fechten and schirmen, see Hils (1985a:244-247). The term schule keeps the same double meaning as the Latin word ludus, meaning "play" or "school" (Amberger, 2007:179). 
middle-class to fellow workers. In itself, it is not surprising to find the same actors wielding swords as a recreational, proto-sportive or competitive activity along with their military obligations in urban militias or watch. Especially as the guild system already gathered marksmen (bow, crossbow and arquebus), at least from the fourteenth century onwards, in many cities (Amberger, 2007:179; Galas, 2011:137) in connection with, on one hand military activities (defence of the town), on the other hand with festive activities (shooting competitions, see Schaufelberger, 1972:119-139; Tlusty 2011:191-198).

The term "fechtschule" appears in the Council books (Ratsbücher) of ancient Swiss Confederation cities in the second half of the fifteenth century. Thus in 1463, the Council of the city of Lucerne, regarding "the many Fightschools, which were held on the place of the City hall", states "that nobody from now on shall fight or fence in front of the City Hall, whoever he is." 33 Other similar mentions refer to gatherings alikes in Basel 1445, Zürich 145434, Lucerne 1459, without the term "Fightschool", but we cannot be mistaken about the type of event, since "Fightmasters" or "Fightteachers," are involved in those, under "School regulations" (schulrecht) 35 .

The same events occur in the southern cities of the Holy Roman Empire: Augsburg, Strasbourg, Frankfurt am Main, Cologne, Freiburg in Bresgau, Munich, Nuremberg; but also Bruges, Prague, Wroclaw, Lübeck, Gdansk, Krakow, etc. Most of these cities were granted franchises (thus are referred to as "Free cities") and were major center for guild's activities and warfare, as pointed out by Chandler (2012) ${ }^{36}$. Nuremberg is certainly the most famous, held - mistakenly - by historiography as the first city to hold a Fightschool ${ }^{37}$. Indeed, the Emperor Frederick III delivered in 1487 a letter of privilege to the Brotherhood of Saint Marcus (referred to as Marxbrüder), a guild of Fightmasters ${ }^{38}$. This document affixed the imperial seal on a process of professionalization rooted much

33 sexta post assumptionis Marie. Item bring an beid ret und bundert von der schirm oder fechtschul wegen, di ettlich baben wellent uff dem rathus [...] dz niemann me fürbin uff dem ratthuss sol schirmen oder fechten, er sy, wer, der wel. Luzern, Staatsarchiv, Ratsprotokoll 5 B (1463), f 210v, quoted in Schaufelberger (1972:141).

34 This event (Stadt Archiv Zürich, B VI, 219, fol. 124r-126v) is quoted by Hils (1985a:176). He indentifies the Fightmaster involved as Hans Talhoffer, author of several Fighbooks. But he is mistaken, since it appears in the document that the Fightmaster is a Hans Tachselhofer, coming from nearby Tachselhofen. See Kleinau (2011).

35 Schirmmeister, lermeister, nach schuelrecht. See Jaquet (2010:77-87). Several sources quoted out of Schaufelberger 1972:141-146). Regarding "school regulation", the term appears twice in the corpus studied. Such document are nowhere yet to be found for the period.

36 Unpublished lecture given in Boston Sword Gathering VIII by Jean Chandleur: "Butchers, Bakers and Candlestick makers - Who wielded the swords in sport and war in the time of the fencing masters".

37 The guild record go back to 1477. See Wasmannsdorff (1870) and Schaer (1901) and most of the quoted authors of reference regarding martial arts. Actually, the first known guild statutes (Saint Michael Guild) dates back to 1456 in Bruges, see Galas (2011:137-141).

38 Edited in Huhle-Brunck (1987:28-30). 
earlier, at least since the late fourteenth century 39 . This document allows a brotherhood 40 to claim occupation's exclusivity, the right of electing their members, to produce documents regulating their practice and the right to punish offenders. These points represent most of the criteria of professionalism, in the modern sense of the term.

The masters of the sword who exercised their expertise in these Fightschools would come in direct line with the ancient gladiators according to Schaer (1901:13), stressing the continuity between the ancient practices of the ars dimicatoria and various forms of public duels during the Middle Ages. The connection is worth considering, a little daring, perhaps, but should be retained especially for the case of duel champions (campiones). During the thirteenth century compilation of customary law record and set ancient customs giving the opportunity to an individual involved in a trial by battle to be represented by a third party, subject to certain conditions (Hils, 1985b:328-340). These professional fighters were of low social status, close to the status of ancient gladiatores by having "no rights" 41 and thus, legally speaking, allowing them to be murdered without any consequence. The system runs out of steam in the course of the fourteenth century, when the judicial duel is restrained to specific cases and slowly replaced by the investigation procedure - at least this is the will of the authorities -, although still resists prohibitions of spiritual and temporal powers until the middle of the sixteenth century (Cavina, 2005 ; Neumann, 2010, Tlusty 2011:106-107).

Another element would link these fighting praxis with Antiquity. The Meistersanger Hans Sachs, shoemaker and a Marxbruder in Nuremberg wrote a fighting song (Fechtspruch) in 1555 alongside with ca. 6000 works. In the poem, he asks a Fightmaster about the genesis of the art of combat (Ursprung der ritterlichen Kunst). It dates from the Olympic Games, founded by Hercules and widespread by roman gladiators (quoted in Ellis 1986:48). Further on, when the rhetorical question of why fighting is no more customary, he answers that the fighting was now a leisure time activity (Kurtzpei i), but still noble (Adelich) like jousting or tourneying, playing string instrument and that it is good for the body and a pleasure to watch for olds and young, also allowing courageous and manly men to win prices, honour and reputation 42 .

These "sword players", some of them to be considered professional fighters, were from middle to low social extraction (Hils, 1995:201-219; Tlusty, 2011:130). Whether taking part in judicial duels, entertaining the crowds, teaching their art or participating in public competitions, their praxis is difficult to grasp, alongside with social "categories" such as

39 The genesis of these praxis is debated among researchers. S. Wetzler traces a ban on holding fencing school in London in 1189 (2012:65). Many others cite the reference to the 7 masters of the sword in Paris 1292 from tax roll, as well as the bans on students to participate in various Fightschools at Universities (Prague 1348, Vienna 1365, Heidelberg 1386, Erfurt 1392). All, however, agree to place the development of these practices in the fifteenth century. See for instance Anglo (2000:7-18), Galas (2011:38-140), Amberger (2007:177-181), etc.

40 Similar from the legislative point of view to a guild or craft corporation.

41 Sachsenspiegel (I.38\$1): Kemphen und iriu kint, spilliute und alle die eneliche geborn sint [...], die sint alle rehtlos (Ssp, I.38). "fighter, children, jugglers and bastards [...] they have no rights". Quoted in Hils (1995:204)

42 This passage is quoted fully in Schmied-Kowarzik - Kufahl (1894:10-11) and partially translated in Amberger (2007:185). 
jugglers (spilleute) with which they are often associated, see fig. $2^{43}$ and 344 . They are migrants (Schubert 1995:226-244; Tlusty 2011:211), moving to exert their practices, like craft guilds journeymen, seeking protection - financial and legal - which they can acquire at the end of the Middle Ages within the walls of a city, at the service of princes or by winning/earning membership in a guild.

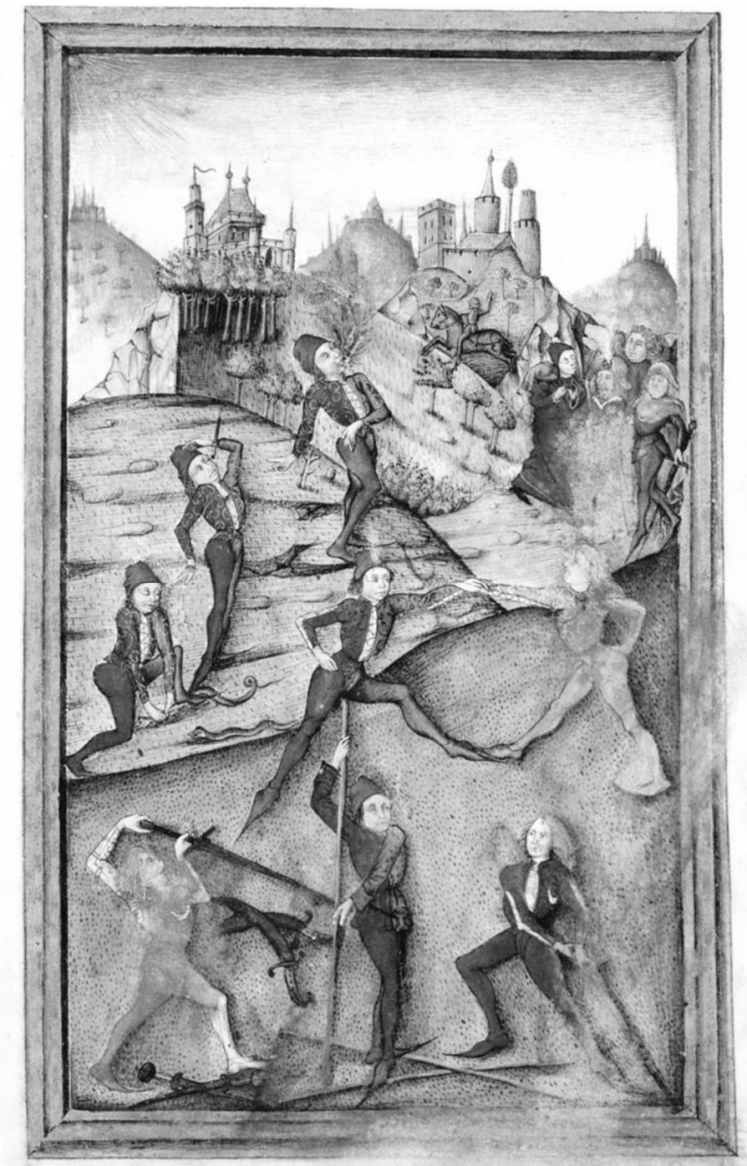

Fig. 2: Anonymous, [Hausbuch von Schloss Wolfegg7, 1480, fol. 3r. Edited in Graf zu Waldburg Wolfegg (1997)

43 At first sight: a pair of swordplayer with their referee with several weapon types to the ground alike to those described in Fightbooks. At second sight: a pair of wrestler. At third sight: a snaketamer, a sword-swallower and a fire-eater. These connections between fighters and jugglers are also often made in "Planetenbilder" illustrations, see Grasshoff (1976:218-232). I shall thank Christian Jäser for this reference.

44 At first sight: an acrobat. Other popular games are depicted in this engraving: ball play, stone throwing, shooting. To be noted as well, the bath scene to the right, associating pleasure with Fightschools. 


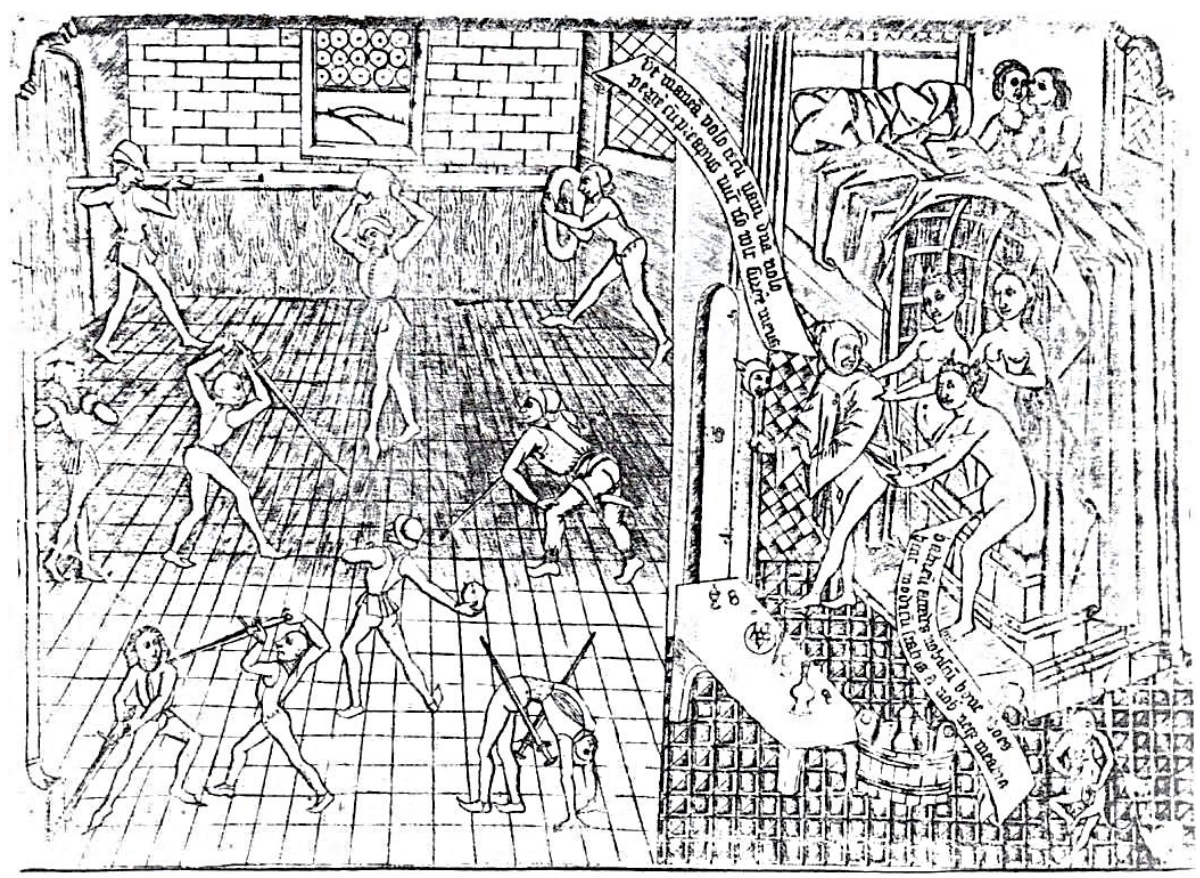

Fig. 3: Master of the Banderolles, engraving, c.1464. Cited in Anglo (2000:14).

\section{PETER SCHWYZER VON BERN, SWORD PLAYER AND MASTER OF THE SWORD}

In order to plot their history, the difficult task of collecting sources that mention the passage of these migrants must be undertaken. I propose to follow the footsteps of one of them, Peter Schwyzer, and at the same time to outline the realities and practices behind the Fightschools 45 .

In 1485, he worked at Baden in canton Aargau, with the support of the City council and the Countess, as a "Fightmaster in all knightly weapons." These weapons are listed below: "sword, long knife, dagger, staff or spear, battle-axe and halberds or any other local weapons" and these "on foot or on horseback." 46 It is interesting to note that this list matches exactly the different weapons addressed by the Hugo Wittenwiler in his Fightbook cited in introduction. Still in Baden, he proclaims:

45 For a more detailed version of this case study, see Jaquet (2010:77-87). Several sources quoted out of Schaufelberger (1972:144-145).

46 Aller riterlichen geweren bewerter vächtmeister hie zuo Baden ufstund [...] Schwert, messer, tägen, stangen oder

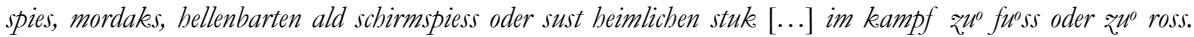
Stadtarchiv Baden, quoted from Welti (1895:449). 
"If someone, whoever he is, [is willing to do] with me in good friendship and company a free bout in a circle, for some gold coins or for free bleeding wounds from a blow, I shall not withdraw, indeed I'll do it confidently. ${ }^{47}$ "

This reference is interesting for several reasons, as it shows some details of these regulated fighting praxis, but also their possible stakes. Money is not surprising, but the mention of a bout achieved by blood deserves further comments. The struggle for "first blood" recalls of course a form of regulation for civil duels of honour from the end of the sixteenth century onwards (Frevert, 1991:26; Brioist-Drévillon-Serna, 2002:52), and still persisting in the nineteenth century Mensur practices (Biastoch 1995, Krug-Richter 2012). In fact, it is part of a very ancient tradition that can be traced back to Antiquity. In the twenty-third book of the Iliad, the funeral games of Patroclus are related. After chariot races, boxing matches, wrestling matches and running races, duels to the first blood are the last games 48 .

This relatively early mention of a bout ended by first blood is then to be considered with precautions. Nevertheless a contemporary mandate for the organization of a "tournament", or rather a Fightschool, in Strasbourg mentions that the bouts were sorted out by the highest bleeding wound (hohsten bluotrür) 49 . Various accounts of sixteenth century Fightschools show that the blood was indeed spilled, even though it was forbidden to draw blood, especially that of beginners (Amberger 2007:184). For example, rule statements, claimed before the competition by the captain of the hosting guild - like the cri of the fifteenth century tournaments -, aim towards preservation of one's life:

"Everyone must know what shall be probibited at this Fightschool, such as thrust, pommel strike, points, entering in wrestling, breaking of arms, bitting to the family jewels, eye-gouging, throwing rocks and all dishonest tricks, as many know well how to apply, that I cannot name all since I haven't learned them. No one shall strike above or below my staff!" 50

47 ob jemand, wer der wer, so mit mir in guoter fründ- und gselschaft umb ein kerenzly ffry streich, umb ein par guldin oder umb ein frye blutruns de ruor $z u^{0}$ fechten begerte, dann sol es von mir unverseit, sonder frischlich bestanden. Konzeptbuch in Stadtarchiv Baden, quoted from ibidem.

48 "To win these prizes invite we warriors twain, the best there are, to clothe them in their armour and take bronze that cleaveth the flesh, and so make trial each of the other before the host. Whoso of the twain shall first reach the other's fair flesh, and touch the inward parts through armour and dark. blood, to him will I give this silver-studded sword - a goodly Thracian sword which I took from Asteropaeus; and these arms let the twain bear away to hold in common; and a goodly banquet shall we set before them in our huts." Homer, Illiad, book 23, 797. English translation Murray.

49 See the contribution of Olivier Dupuis in this volume (Dupuis, 2013, p. 67).

50 Jedoch soll ein jeder wissen, was auff dieser Fechtschul soll verbotten sein, als Ort, Knopff, Spitz, Einlauff, Armbüch, Gemächtstoss, Augengrieff, Steinworff und alle unredliche Stück, die mancher wol zubrauch weisz, die ich nicht alle erzeblen kann, und auch nicht gelernet habe, auch schlage mir keiner über noch unter die Stangen (Schmied-Kovarzik - Kufahl, 1894:145) 
Underlining the relation between Fightschools and Fightbooks, these tricks match the forbidden wrestlings (verpotten ringen) described by glossators of the Liechtenauer's Epitome from 1452 onwards in the duelling to the bitter end section (Kampffechten ${ }^{51}$ ) that are to be "forbidden by all wise masters of the sword (maistern des swertis)" and "that which schoolfencers (schulfechtern) are not allowed to learn or even see"52.

Peter Schwyzer seems to have moved thereafter to Basel where he appears in the sources as "master" and holds Fightschools from 1490 onwards (Mathys, 1954:26-27). In 1492, the City Council supports him by giving him exclusive rights and warranty against rivals:

"Once and henceforth, Peter Schuyzer of Bern is only authorized to bold the Fightschool, with this warranty, if someone comes and wants to strike down his sword, willing to undertake it, so shall he defend it by the sword. Then Paulus the Fightmaster who also beld schools came to undertake it."

"Striking down the sword" (swert abbiewe), symbol of the Master suspended in plain sight during the Fightschool, is a challenge to a duel. This ritualized gesture is reminiscent of contemporary chivalrous games (pas d'armes), where the challenger must hit a shield or an object symbolizing a champion or a type of combat (on horseback, on foot, with specific weapons, etc.). Maintaining the school "by the sword" means the right to a duel. In the beginning of the century a Fighmaster author of Fightbooks, Fiore dei Liberi, claims to have survived unharmed five of such duels against rivals, in civil clothing and leather gloves with sharpened swords ${ }^{54}$. Neither normative sources, nor chronicles mention a duel between Peter Schwyzer and this Paulus, who would have waived his rights according to Ochs (1821:94).

He maintained his activities now and then in Basel and wore a "silver coat with the arms of the city. 55 " He was replaced in 1518 by Hans Glarner as appointed Fightmaster for

51 These are: arm break, leg break, knee thrust, testes thrust, finger wrench and eye gouge. The first gloss of Liechtenauer Kampffechten section is to be found in the compilation of Peter von Danzig in 1452 (Roma, Academia Nazionale dei Lincei, Cod.44.A.8, fol. 53r-72r), but copied several times at least until 1570 in the manuscript of Joachim Meyer (Rostock, Universitätsbibliothek, Ms Var.82, fol.98r-110r).

52 So wart das du die ringen weisleich zw weg pringest und treibest die do ver poten sein von allen weisen maisterñ des swertz das man die auf offenwarñ schüllen chainen schülfechterñ lernen sol noch sehen sol lassen dar vmb das sï zw dem champf gehören das sein arm prüch und painprüch vnd knüe stöss vnd hoden stöss vnd vinger lösung und augen griff. Quoted from Hagedorn (2008:156)

53 Demnoch und hiervor Peter Switzer von Bern die fechtschuol allein bie zugelassen ist, doch mit dem fürworten, ob jemand barkäme und im sin swert abbiewe, als den ir harkommen ist, dasz er die schuol unterstande dann mit dem swert zu behalten. Und aber paulus der fechtmeister ouch ein schuol uffgericht und undersat schuol zu halten. Basler Erkenntnisbuch (1492) quoted in Mathys (1954:27)

54 Fiore dei Liberi's Fightbooks, 1409. Edition Rubboli-Cesari (2002). Related in the first prolog (Morgan version fol.1v p.29, Getty version, fol.3v, p.26).

55 Ein silbernes Kleinod mit dem Stadtwappen getragen" quoted in Wackernagel (1968:105 - vol.III) 
Basel. His departure to Freiburg im Breisgau is mentioned. An order placed in Bern in 1504 leaves a trace in the records of the city and attests his activity as Fightmaster there as well (Haller, 1902:136 - vol.III). Finally he is to be found as the captain of a swordfighting guild for the years 1498 to 1500 in the statutes of the masters of the sword in Frankfurt (Franckfuibrter Fechter Ordnung des Maister des Langen Schwert) ${ }^{56}$.

Throughout this collection of documentary references, without having done extensive research on the character, it is already possible to assert that Peter Schwyzer von Bern was a representative of the Fightmaster's occupation, carrying his expertise in various places and holding numerous Fightschools. He left traces in over five cities across the ancient Swiss Confederation and southern provinces of the Holy Roman Empire between the years 1485 and 1518. He was a recognized Fightmaster, both by town authorities and swordfighting guilds, as he was appointed as a captain of a latter where his name appeared in company of famous Fightmasters, including some that have left us surviving Fightbooks ${ }^{57}$ (original footnote no. 20). It was also possible to perceive some sociologic and praxeologic details of the Fightschool; some glimpses of the relation between Fightmasters and town authorities; some aspects of the tensions created by Fightmaster's rivalries; as well as the connection of such events and the Fightbooks.

This article aimed to emphasize the strong link between the technical literature of the Fightbooks and one of its contexts of application: the Fightschools. Within the Fightbooks, the representation (textual and iconographic) of the art combat, as well as the self-representation of the authors allows to delineate socio-cultural conceptions of the art. The playful and the serious dimensions of the art allow us to gain insights into what mostly fail to be described: the finality of the gesture. The study of competitive, leisure of festive praxis is hence crucial.

For the considered period, the paratext of this literature is so poor and such little academic research on the matter has been undertaken, that it is hard to establish the intended context of application of these treatises, as well as their role in the process of embodied knowledge transmission (didactic, utilitarian, collectable dimensions?). Too little evidence of a connection with warfare and men-at-arms training per se leads researchers to disregard this context of application (Anglo, 2000:271-271; Amberger 2007:185; Tlusty 2011:211). Few of the Fightbooks and their Fightmasters can be connected with the aristocracy (especially in the context of preparation for judicial or honour duels), but most of these can be linked to the Fightschools praxis. So the Historical European Martial Arts research field definitely needs further studies on

56 Anno 1498 jst petter Schweizer von Bern haubtman worden So hat Er von den maystern Empfangen 46 s jn gold vnnd Bleibt jn der Bux Ein Schildt / vnnd silbern ketten, vnnd seind alle ding sunst bezalt vnd auch die Bruder des conuents vnnd so bald 1 kron vff die Engel geben zumach<en>. Quoted after Dupuis (2009:24).

57 See note 20. 
Fightschools, especially for its earlier period, the fifteenth and early sixteenth century 58 . These would offer insights into, on one hand, the praxeology of civil regulated single combats, on the other hand, the sociology of its actors, both key elements to understand the Historical European Martial Arts.

\section{CITED BIBLIOGRAPHY}

Amberger, Christoph J. (2007): „Killing arts or upper-class leisure activity?: Aspects of European combatives in image and literature". In: Molloy, Barry (ed.) The Cutting Edge: Studies in Ancient and Medieval Combat. Stroud: Tempus. pp 177-187.

Anglo, Sydney (2000): The Martial Arts of Renaissance Europe. New Haven: Yale University Press.

Barber, Richard; Barker, Juliet (1989): Tournaments: jousts, chivalyy and pageants in the Middle Ages. Woodbridge: The Boydell Press.

Barbey, Francis. (1911-1912): « Orbe sous les sires de Montbéliard et de Chalon: d'après les comptes inédits de la ville ». Revue Historique Vaudoise. 19 et 20.

Bauer, Matthias Johannes (Hrsg.) (2009): Langes Schwert und Schweinespiess: die anonyme Fechthandschrift aus den Verschütteten Beständen des Historischen Archivs der Stadt Köln. Graz: Akademische Druck- u. Verlagsanstalt.

Bergner, Ute; Giessauf, Johannes (Hrsg.) (2006): Würgegriff und Mordschlag: die Fecht- und Ringlehre des Hans Czynner (1538): Universitätsbibliothek Graz, Ms. 963. Graz: Akademische Druck- u. Verlagsanstalt.

Biastoch, Martin (1995): Duell und Mensur im Kaiserreich. am Beispiel der Tübinger Corps Franconia, Rhenania, Suevia und Borussia zwischen 1871 und 1895. Vierow: SH-Verlag.

Bodemer, Heidemarie (2008): Das Fechtbuch. Untersuchungen zur Entwicklungsgeschichte der bildkünstlerischen Darstellung der Fechtkunst in den Fechtbüchern des mediterranen und westeuropäischen Raumes vom Mittelalter bis Ende des 18. Jahrhunderts. Ph.D. Philosophisch-Historischen Fakultät der Universität Stuttgart.

Bove, Boris (2003): „Les joutes bourgeoises à Paris, entre rêve et réalité (XIIIe-XIVe s.)”. In: Le tournoi au Moyen Age. Lyon (Cahiers du centre d'histoire médiévale). pp 135-163.

Brioist, Pascal; Drévillon, Hervé; Serna, Pierre (2002): Croiser le fer: Violence et culture de l'épée dans la France Moderne (XVIe-XVIIIe siècle). Seyssel: Champ Vallon.

Cavina, Marco (2005): Il sangue dell'onore: Storia del duello. Roma: Laterza.

Chandler, Jean (2013): A brief examination of warfare by medieval urban militias in Central and Northern Europe. Acta Periodica Duellatorum, Vol. 1. Havana Consulting.

Contamine, Philippe (2003): La guerre au Moyen Âge. 6th revised edition. Paris: Presses universitaires de France (Nouvelle Clio).

58 From the second half of the sixteenth century onwards, more material is available allowing to grasp the Fightschool's praxis. Some late nineteenth, early twentieth publications (quoted in this article) collected references on the matter, but no extensive research, monographies or even articles addresses directly the issue. Few chapters or articles investigated this matter (Schaufelberger, Hils, Anglo, Galas, Amberger, Tlusty, Dupuis and Jäser) but this definitely needs fundamental research and networking of local researchs. 
Dupuis, Olivier (2009): „Transkription der Handschrift I.6.2 .5”. In: Pragmatische Schriftlichkeit. [online] available at http://www.pragmatischeschriftlichkeit.de/transkription/Cod.I.6.2.5._16.03.09.pdf [accessed 21.12.2009].

Dupuis, Olivier (2013): A fifteenth-century fencing tournament in Strasburg. Acta Periodica Duellatorum, Vol.1. Havana Consulting.

Ellis, Frances (1986): „„,Der olimpisch Kampff’ A Meisterlied of Hans Sachs”. In: Monatshefte. 78 (1). pp 48-53.

Fleckenstein, Josef (Hrsg.) (1986): Das ritterliche Turnier im Mittelalter: Beiträge zu einer vergleichenden Formen- und Verbaltensgeschichte des Rittertums. Göttingen: Vandenhoeck \& Ruprecht.

Forgeng, Jeffrey (2012): „Owning the Art: The German Fechtbuch Tradition”. In: Capwell, Tobias (ed.) The Noble Art of the Sword: Fashion and Fencing in Renaissance Europe 1520-1630. London: Paul Holberton Publishing. pp. 164-175.

Frevert, Ute (1991): Ehrenmänner: das Duell in der bürgerlichen Gesellschaft. München: C.H. Beck.

Galas, Matt (2011): „Statutes of the Fencing Masters of Bruges (1456)”. In: Cognot, Fabrice (éd.) Arts de combat. Théorie \& Pratique en Europe - XIVe-XXe siècle. A.E.D.E.H. Paris (Histoire et patrimoine). pp 137-152.

Graf zu Waldburg Wolfegg, Christoph (1997): Das mittelalterliche Hausbuch aus der Sammlung der Fürsten zu Waldburg Wolfegg. München: Prestel.

Grangier, Jean-Paul (1905): Annales d'Estavayer.

Grasshoff, Kurt (1976): „Leibesübungen in Planetenkinderbildern des 15. und 16. Jahrhunderts: Die Kinder des Planetengottes Sol.”. In: Stadion 2. pp 218-232.

Hagedorn, Dierk (2008): Peter von Danzig: Transkription und Übersetzung der Handschrift 44 A 8. VSBOOKS Torsten Verhülsdonk.

Haller, Berchtold (1902): Bern in seinen Rathsmanuelen 1465-1565. Vol. II. Bern: K.J. Wyss.

Hauser, Albert (1987): Was für ein Leben: Schweizer Alltag vom 15. bis 18.Jabrbundert. Zürich: Neue Zürcher Zeitung cop..

Heers, Jacques (1982): Fêtes, jeux et joutes dans les sociétés d'Occident à la fin du Moyen Age. Montréal; Paris: Inst. d'études médiévales; Vrin (Conférence Albert-Le-Grand).

Hils, Hans-Peter (1985a): Meister Johann Liechtenauers Kunst des langen Schwertes. Frankfurt am Main; New York: P. Lang.

Hils, Hans-Peter (1985b): ,„,Der da sigelos wirt dem sleht man die hant ab”. Zum Stand der hauptberufliuchen Fechter nach mittelalterlichen Rechtsquellen”. In: Zeitschrift der SavignyStiftung für Rechtsgeschichte: Germanistische Abteilung, 102. pp 328-340.

Hils, Hans-Peter (1995): „Reflexionen zum Stand der hauptberuflichen Fechter des Späten Mittelalters unter Berücksichtigung historischer Rechtsquellen”. In: Keil, Gundolf (Hrsg.) Würøburger Fachprosa-Studien: Beiträge zur mittelalterlichen Medizin-, Pharmąie- und Standesgeschichte aus dem Würžburger medizinhistorischen Institut. Michael Holler zum 60. Geburtstag. Würzburg: Königshausen \& Neumann (Würzburger medizinhistorische Forschungen). pp 201-219.

Huhle, Henner; Brunck, Helma (Hrsg.) (1987): 500 Jabre Fechtmeister in Deutschland: Ältester Privilegierter Berufsstand. Frankfurt am Main: Historisches Museum (Kleine Schriften des Historischen Museums Frankfurt). 
Jaquet, Daniel (2005): Item wiltu lernen hoflich und weidalich mit dem langen schwert vechten "Maintenant tu vas apprendre à combattre courtoisement et vaillamment avec l'épée longue. » : Étude d'bistoire des techniques sur un traité d'escrime suisse du XVème siècle. MA thesis, University of Geneva.

Jaquet, Daniel (2010): „Entre éducation et festivité : Schirm- und Fechtschulen dans l'ancienne Confédération suisse, XVe-XVIe siècles". In: Meuwly, Olivier (éd.) Duel et combat singulier en Suisse romande: de l'Antiquité au XXe siècle. Bière: Cabédita (Archives vivantes). pp 77-87.

Kiermayer, Alex - Forgeng, Jeffrey (2007): ,„,'The Chivalric Art”: German martial arts treatises of the Middle Ages and Renaissance". In: Molloy, Barry (ed.) The Cutting Edge: Studies in Ancient and Medieval Combat. Stroud: Tempus. pp 153-167.

Kleinau, Jens-Peter (2011): “The Tachselhofer of Zurich" in Hans Talhoffer Blogspot, [online] available at http://talhoffer.wordpress.com/2011/04/21/hello-world/ [accessed 30.12.2012].

Krug-Richter, Barbara (2012): „Ein stund ernennen unnd im ein schlacht lieffern. Anmerkungen zum Duell in der studentischen Kultur". In: Ludwig, Ulrike; Krug-Richter, Barbara; Schwerhoff, Gerd (Hrsg.) Das Duell - Ehrenkämpfe vom Mittelalter bis zur Moderne. Konstanz: UVK Verlagsgesellschaft. pp 275-287.

Leng, Rainer et al. (2008): Katalog der deutschsprachigen illustrierten Handschriften des Mittelalters Band 4/2, Lfg. 1/2: 38: 38. Fecht- und Ringbücher. C.H. Beck. München: Bayerische Akademie der Wissenschaften.

Mathys, Fritz Karl (1954): Spiel und Sport im alten Basel. Basel: Cratander.

Mehl, Jean-Michel (1990): Les Jeux au Royaume de France du XIIIe au début du XVTe siècle. Paris: Fayard.

Mehl, Jean-Michel (2010): Des Jeux et des Hommes dans la société médiévale. Paris: H. Champion.

Meier, Andreas (2010): «Talhoffers Fechterkollegen ». In: Schulze, André (Hrsg.) Der Königsegger Codex: die Fechthandschrift des Hauses Königsegg. Mainz am Rhein: Philipp von Zabern.

Meier, Christel (Hrsg.) (2003): Träger, Felder, Formen pragmatischer Schriftlichkeit im Mittelalter : Bericht über die Arbeit des Sonderforschungsbereichs 231 an der Westfälischen Wilhelms-Universität Münster ; 1986 - 1999. Münster: De Gruyter.

Morsel, Joseph (2000): „L'invention de la noblesse en Haute-Allemagne à la fin du Moyen Âge. Contribution à l'étude de la sociogenèse de la noblesse médiévale". In: Paviot, Jacques; Verger, Jacques (éd.) Guerre, Pouvoir Et Noblesse Au Moyen Âge: Mélanges En L’honneur De Philippe Contamine. Paris: Presses de l'Université de Paris-Sorbonne (Cultures et civilisations médiévales). pp 533-545.

Morsel, Joseph (2004): L'aristocratie médiévale: la domination sociale en Occident (Ve-XVe siècle). Paris: A. Colin (U. Histoire).

Müller, Jan-Dirk (1992): „Bild - Vers - Prosakommentar am Probleme der Verschriftlichung Beispiel von Fechtbüchern. einer schriftlosen Praxis.”. In: Keller, Hagen; Grubmüller, Klaus; Staubach, Nikolaus (Hrsg.) Pragmatische Schriftlichkeit im Mittelalter : Erscheinungsformen und Entwicklungsstufen: (Akten des Internationalen Kolloquiums, 17. - 19. Mai 1989). München: W. Fink. pp 251-282.

Müller, Jan-Dirk (1994): „Hans Lecküchner Messerfechtlehre und die Tradition”. In: Müller, JanDirk (Hrsg.) Wissen für den hof der spätmittelalterliche Verschriftungsprozess am Beispiel Heidelberg im 15. Jabrhundert. München: W. Fink (Münstersche Mittelalter-Schriften). pp 355-384. 
Nadot, Sébastien (2012): Le spectacle des joutes: sport et courtoisie à la fin du Moyen Age. Rennes: PU Rennes.

Neste, Evelyne van den (1996): Tournois, joutes, pas d'armes dans les villes de Flandre à la fin du Moyen Age: (1300-1486). Paris: Ecole des Chartes (Mémoires et documents de l'Ecole des Chartes).

Neumann, Sarah (2010): Der Gerichtliche Zweikampf: Gottesurteil, Wettstreit, Ehrensache. Ostfildern: Jan Thorbecke Verlag.

Ochs, Peter (1821): Geschichte der Stadt und Landschaft Basel. Vol.V. Basel: Schwieghauser'schen Buchhandlung.

Prietzel, Malte (2012): „Schauspiele von Ehre und Tapferkeit. Zweikämpfe in Frankreich und Burgund im späten Mittelalter". In: Ludwig, Ulrike; Krug-Richter, Barbara; Schwerhoff, Gerd (Hrsg.) Das Duell - Ehrenkämpfe vom Mittelalter bis zur Moderne. Konstanz: UVK Verlagsgesellschaft. pp 105-124.

Rondi, Peter (ed.) (1950): Eisenacher Rechtsbuch. Vol. 3, Weimar: H. Böhlaus Nachf (Germanenrechte. Neue Folge. Stadtrechtsbücher).

Rösener, Werner (Hrsg.) (2000): Adelige und bürgerliche Erinnerungskulturen des Spätmittelalters und der Früben Neuz̨eit. Göttingen: Vandenhoeck \& Ruprecht (Formen der Erinnerung).

Rubboli, Marco - Cesari, Luca (ed.) (2002): Flos duellatorum : manuale di arte del combattimento del XV. secolo. Rimini: Il cerchio.

Rubboli, Marco - Cesari, Luca (ed.) (2005): L'Arte cavalleresca del combattimento. Rimini: Il Cerchio (Archi (Gli)).

Schaer, Alfred (1901): Die altdeutschen fechter und spielleute: Ein beitrag zur deutschen culturgeschichte. K.J. Trübner.

Schaufelberger, Walter (1972): Der Wettkampf in der alten Eidgenossenschaft: zur Kulturgeschichte des Sports vom 13. bis ins 18. Jahrhundert. Bern: P. Haupt (Schweizer Heimatbücher).

Schmied-Kowarzik, Josef; Kufahl, Hans (1894): Fechtbüchlein. Leipzig: Philipp Reclam jun.

Schubert, Ernst (1995): Fabrendes Volk Im Mittelalter. Bielefeld: Verl. für Regionalgeschichte.

Stangier, Thomas (2009): „Ich hab herz als ein leb... Zweikampfrealität und Tugendideal in den Fechtbüchern Hans Talhoffers und Paulus Kals”. In: Niehoff, Franz (Hrsg.) Ritterwelten im Spätmittelalter. Museen der Stadt Landshut. Landshut (Schriften aus den Museen der Stadt Landshut). pp 79-93.

Tlusty, B. Ann (2011): The Martial Ethic in Early Modern Germany: Civic Duty and the Right of Arms. Basingstoke: Palgrave.

Tobler, Christian (2010): Captain of the Guild: Master Peter Falkner's art of knightly defense. Wheaton: Freelance Academy Press.

Verrier, Frédérique (1997): Les armes de Minerve: l'humanisme militaire dans l'Italie du XVTe siècle. Paris: Presses de l'Université de Paris-Sorbonne (Jalons. Nouvelle série).

Wackernagel, Rudolf (1968). Geschichte der Stadt Basel. Reprint, first edition 1907. 4 vol. Basel: Heibling \& Lichtenbahn.

Wassmannsdorf, Karl (1877): „Kaiser Friedrich's III. Privilegiumsbrief an die deutschen Meister des Schwerts”. In: Turnzeitung, 21. pp 137-139. 
Wassmannsdorff, Karl (1870): Sechs Fechtschulen (d. i. Schau- und Preisfechten) der Marxbrüder und Federfechter aus den Jahren 1573 bis 1614; Nürnberger Fechtschulreime v. J. 1579 und Rösener's Gedicht: Ehrentitel und Lobspruch der Fechtkeunst v. J. 1589: Eine Vorarbeit zu einer Geschichte der Marxbrüder und Federfechter. Heidelberg: Karl Groos.

Welle, Rainer (1993): ,...und wisse das alle höbischeit kompt von deme ringen”: der Ringkampf als adelige Kunst im 15. und 16. Jahrhundert : eine sozialhistorische und bewegungsbiographische Interpretation aufgrund der handschriftlichen und gedruckten Ringlehren des Spätmittelalters. Pfaffenweiler: Centaurus-Verlagsgesellschaft (Forum Sozialgeschichte).

Welti, Friedrich-Emile (1895): « Kulturgeschichte Mitteilungen » in: Anzeiger für schweizerische Altertumskunde 7.

Wetzler, Sixt (2012): „Überlegungen zur europäischen Fechtkunst”. In: Ludwig, Ulrike; KrugRichter, Barbara; Schwerhoff, Gerd (Hrsg.) Das Duell - Ehrenkämpfe vom Mittelalter bis zur Moderne. Konstanz: UVK Verlagsgesellschaft. pp 60-75.

Wierschin, Martin (1965): Meister Johann Liechtenauers Kunst Des Fechtens. München: C.H. Beck (Münchener Texte und Untersuchungen zur deutschen Literatur des Mittelalters).

Zabinski, Grzegorz (2010): The Longsword Teachings of Master Liechtenauer: The Early Sixteenth Century Swordsmanship Comments in the „Goliath” Manuscript. Torun: Wydawnictwo Adam Marsz. 